\title{
Analysis Of Water Performance At Graha Jangli Indah Semarang
}

\author{
Suharyanto $^{1}$, Budiono Joko Nugroho ${ }^{2}$, Sri Sangkawati ${ }^{3}$ \\ Civil Engineering, Diponegoro University ${ }^{1,3,}$ Civil Engineering,Universitas 17 Agustus 1945 \\ Semarang, ${ }^{2}$ \\ Email: budionojoko@untagsmg.ac.id \\ DOI: http://dx.doi.org/10.31869/rtj.v4i1.1903
}

\begin{abstract}
The clean water network system is made to meet the needs of clean water in a city or community and for Graha Jangli Indah, clean water management is carried out by the Graha Jangli Indah Water Management. The purpose of this study is to find out the performance of clean water network services managed by the Water Management Board of Jangli Indah by analyzing the network service performance of the network's ability to meet the minimum needs of customers in terms of water discharge. In addition, an analysis of customer satisfaction was carried out on the Water Management of Graha Jangli Indah. the level of clean water service network at Graha Jangli Indah is still unsatisfactory, with a reliability of only around $49.33 \%$, with the length of time the system will be in a state of failure of about 5.83 months, and with a very average percentage deficit discharge rate which varies between $1.12 \%$ to $102.11 \%$. So that the system's resilience index or ability to return to normal conditions is 0.17 (1.03 times failure divided by 5.83 months). This is because the average discharge at Graha Jangli Indah has an average water discharge value of $17.8 \mathrm{~m} 3$ per month which is still below the standard water demand based on Domestic Water Needs for the Big Cities category of $20.4 \mathrm{~m} 3$. For the calculation of the value of have rated the performance of Graha Jangli Indah Management services with very good value. With 7 indicators entering quadrant II so that conclusions can be drawn by the Importance and Performance Analysis (IPA) method, the performance of the Graha Jangli Indah Water Management is quite satisfying.
\end{abstract}

Keywords: clean water, managements, network, performance.

\section{INTRODUCTION}

\section{Background}

Clean water network system is made to meet the water needs of residents of a city or a community. Water sources can come from springs, lakes, rivers or deep ground water. The water is then treated at a water treatment plant so that it meets the clean water standards issued by the Minister of Health and then distributed to consumers. Management of clean water / drinking water services for the people of Semarang City is carried out by the local Municipal / District Water Company (PDAM), which is a government-owned company. For Semarang City, the management of clean water / drinking water services for the community is carried out by the Semarang Municipal Water Supply Company (PDAM)

Coverage of piped water services to residents in the service area of the PDAM, which currently only reaches $45.90 \%$ (BPPSPAM, 2017). This is partly due to the limited capacity of water sources and the capacity of water treatment plants, the lack of optimal distribution transmission networks, limited sources of PDAM funds, and the existence of alternative water sources that cause a lack of community interest in subscribing to PDAM water. In addition, the majority of PDAM customers are still not served by drinking water that meets the quality, quantity and continuity requirements, which is the customer's right due to PDAM services that are not yet effective and efficient.

From the data of PDAM Tirta Moedal Semarang City in Agustus 2019, it was found that the PDAM Tirta Moedal Semarang City only served 173,612 households from 517,083 households (Dispendukcapil Kota Semarang, June 2018) in Semarang City or 33\% of the $80 \%$ service target in the urban population. Due to the hilly topological conditions in the southern part of Semarang City, there are many houses in the southern part of Semarang that are not served by Tirta Moedal PDAM. Each housing that stands up makes a communal clean water and sewerage system to meet the water needs in the residential area.

This study is based on the idea that the operating system of clean water networks in 
the city of Semarang has not produced the expected level of service.

The lack of optimal water services is influenced by several factors including topography, consumer distribution, water availability, operating policies, performance or expected service levels and network development (extension).

Graha Jangli Indah Water Management is a community involvement in improving drinking water services or often called disebut Penyediaan Air Minum Berbasis Masyarakat (PAMBM). Penyediaan Air Minum Berbasis Masyarakat is a drinking water supply system that is initiated, selected, built and funded by the community and / or with the assistance of other parties, managed sustainably by the community based on the agreement of the relevant drinking water user group (PUSKIM, 2012).

The purpose of the study is to find out the performance of clean water services managed by the Water Management at Graha Jangli Indah by analyzing the performance of network services, ability of the network to meet the minimum needs of customers, especially water debit.. In addition, an analysis of water customer satisfaction was carried out on the services performed by the Graha Jangli Water Management.

\section{Formulation Of The Problem}

The assessment of clean water network services in an urban area of customers is still lacking proper attention from the management. This is reflected in the number of customer complaints about the quality of water services. Some of the things that are often complained about insufficient flow, underpressure, the flow is not continuous or the hours of drainage can not be expected, and water quality is not good. Noting the things mentioned above, the problems that arise are:

1. How is the performance of clean water network services primarily based on water discharge from the customer's water meter reading discharge on Reliability, Resiliency and Vulnerability.

2. How is the water customer satisfaction with the Graha Jangli Indah Water Management service.

\section{LITERATURE REVIEW}

Performance can be known from the results of the analysis of the failure of the pipeline and its operation to meet the needs. Some performance indicators must be able to give an indication of how far the intensity of the failure and how long a failure occurred, so that network performance can be known. These performances include minimal reliability, resilience, and vulnerability (Suharyanto, 1999). Analysis of the performance parameters operation of the pipeline network is usually done by evaluating the network based on the average value (mean) and variations (variance) of these parameters. The amount of reliability (reliability) of a pipeline is more emphasized on the percentage of average long-term ability of the pipeline network to meet the needs. In reality, variations in discharge, changes in network configuration, and network operation policies will cause variations in operating performance parameters, so these three factors need to be considered for their effect on the performance of the operation of clean water pipelines. The consequences that occur when the pipe network is not able to meet their needs is when it occurs "Failure" is not given much attention even though the consequences of a failure on the pipeline have a broad impact and last long enough and can also provide a prolonged psychological burden. The use of pipeline reliability performance is not always able to describe the actual behavior of the pipeline network. The performance presented in this study are several performance indicators that are able to give an indication of how far the intensity of the failure and how long a failure occurred. The performance is reliability, resilience and vulnerability.

\section{Reliability}

This performance shows / measures the ability of the pipeline to fulfill its function of meeting needs. Mathematically, the definition of reliability can be written as follows. Where is the $\mathrm{Zt}$ variable, the value is determined by the following equation:

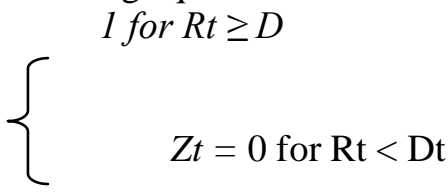


Where $\mathrm{Zt}$ is an indicator or counter to calculate events where Rt, $\mathrm{t}$ Dt, Rt is the service discharge from the pipeline in the period $\mathrm{t}\left(\mathrm{m}^{3} /\right.$ month $)$ and $\mathrm{Dt}$ is water requirements in the period $\mathrm{t}$ (in this case the need is the minimum discharge at the customer). It should be noted that in this definition, failure is interpreted if $\mathrm{Rt}<\mathrm{Dt}$, other than that the mean value is the total amount of time that the pipeline is able to meet its needs.

\section{Resiliency}

In the event of a failure, this resilience performance demonstrates or measures the ability of the pipeline to return to a non-failing state or to a satisfactory state from a "fail" state. The sooner the pipeline returns to its satisfactory state, the consequence of this failure will be smaller. For this reason, it is important to know when the pipeline is experiencing a transition from a state of "failure" to a state of "satisfactory" or vice versa from a state of "satisfactory" to a state of "failure" (In the long run, the transition period of the pipeline from the state of "failing" to " satisfying "will be the same as the pipeline transition period from" satisfying "to being" failed "). In the long run, the average value of Wt (pipeline transition period from "failed" to "satisfactory") will indicate the average number of pipeline transition periods from "failed" to "satisfactory" state. Furthermore, the length (time period) of the average pipeline network is in a "failed" state continuously (sequentially), it can be seen from the total amount of time the average pipeline network has "failed" divided by the average frequency of pipeline transition. Wt variables that can be defined by the equation:

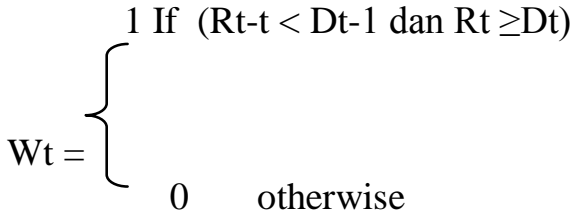

Where Wt is the pipeline transition period from a "failed" state to a "satisfactory" state, Rt-1 is the service debit from the pipe network in the period $\mathrm{t}-1$ ( $\mathrm{m}^{3} /$ month), $\mathrm{D} \mathrm{t}-1$ is the service debit from the pipe network in the period $\mathrm{t}-1$ ( $\left.\mathrm{m}^{3} / \mathrm{month}\right)$, Rt is the service discharge from the pipeline in the period $\mathrm{t}-1$ $\left(\mathrm{m}^{3} /\right.$ month), Dt is the minimum water requirement expected in the period $\mathrm{t}\left(\mathrm{m}^{3} /\right.$ month), Otherwise is the condition under which conditions ( Rt-1 $<\mathrm{D} \mathrm{t}-1$ and $\mathrm{Rt} \geq \mathrm{Dt}$ ) are not met.

The indicator of resilience performance is defined as the inverse value of the average length of time the pipeline is in a "failed" state. The longer the average length of the pipeline is in a state of failure, the lesser the performance of the pipeline or in other words the pipeline will require a relatively longer time for "recovery".

\section{Vulnerability}

If a failure occurs, the performance of vulnerability shows / measures how big vulnerable a failure is. To measure the level of vulnerability used deficit variable. The performance of vulnerability can be defined by various interpretations, including:

a. Maximum value of "deficit"

b. Maximum value of "deficit-ratio"

c. The average value of "deficit-ratio"

To measure the level of vulnerability used deficit variable, DEFt which can be defined as:

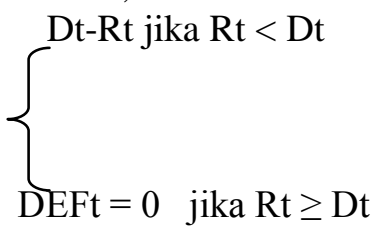

Where DEFt is deficit deficit in period $t$ $\left(\mathrm{m}^{3} /\right.$ month), Dt is the minimum expected water requirement in period $\mathrm{t}\left(\mathrm{m}^{3} /\right.$ month), $\mathrm{Rt}$ is the service debit from the pipeline network in period $\mathrm{t}\left(\mathrm{m}^{3} /\right.$ month).

Assessment of Customer Satisfaction Performance

The process of analyzing customer satisfaction performance from the clean water service quality of the Graha Jangli Indah Water Management, is carried out using the Importance and Performance Analysis (IPA) and Customer Statisfaction Index (CSI). IPA analysis is a method of analysis which is a combination of aspects of the level of importance and perception of the quality or condition of an object in two dimensions (Arimbi, 2015). Importance Performance Analysis (IPA Analysis) is a tool in analyzing or used to compare the extent to which the performance that can be felt by users of the

\begin{tabular}{lll}
\hline ISSN 2599-2081 & Fakultas Teknik UMSB & 3
\end{tabular}

EISSN 2599-2090 
water supply system in Graha Jangli Indah is compared to the desired level of performance. The level of conformity is the result of a comparison between the implementation performance score and the importance score, so this conformity level will determine the priority scale that will be used in the clean water supply indicator that affects the performance of the Graha Jangli Indah community.

\section{Importance}

As a guideline for the Graha Jangli Indah community to assess the importance of the indicator of clean water supply, a scale of 1-5 is used.
1: Very unimportant
2: Not Important
3: Quite Important
4: Important
5: Very important

\section{Level of Performance}

As a guideline for consumers to assess the level of service performance, tooused a scale with a value of 1-5.

1: Very Dissatisfied

2: Dissatisfied

3: Quite Satisfied

4: Satisfied

5: Very Satisfied

The stages of the IPA analysis method are as follows:

\section{Weighting}

The scale used in this study is the Likert scale. Likert scale is generally used in research that is a measurement of attitudes, beliefs, values and opinions of users or consumers of an object's condition.

\section{Quadrant Analysis}

The first step for quadrant analysis is to calculate the average importance and performance ratings for each attribute using the formula:

$$
\begin{gathered}
\overline{X i}=\frac{\sum_{i=1}^{k} X i}{n} \\
\bar{Y} i=\frac{\sum_{i=1}^{k} Y i}{n}
\end{gathered}
$$

Whereas:

$$
\begin{gathered}
\overline{\mathrm{X}}_{1}=\text { Weight of the average level of } \\
\text { performance rating of the } \mathrm{i} \text { attribute }
\end{gathered}
$$

$\overline{Y_{1}}=$ The average weighted level of importance rating attributes $\mathrm{i}$

$\mathrm{n}=$ Number of respondents

The next step is to calculate the average level of importance and performance for the entire attribute using the formula:

$$
\begin{aligned}
& \overline{\overline{X i}}=\frac{\sum_{i=1}^{k} \overline{X i}}{n} \\
& \overline{\overline{Y i}}=\frac{\sum_{i=1}^{k} \overline{Y_{i}}}{n} \\
& \overline{\overline{X_{l}}}=\text { Weight of the average level of } \\
& \overline{\overline{Y_{l}}} \quad \text { performance rating of the } \mathrm{i} \text { attribute } \\
& \mathrm{importance} \text { rating attributes } \mathrm{i}
\end{aligned}
$$

The average value of the importance and performance level scores are used to determine the points in the quadrant. The next interpretation is a combination of importance level scores and the quality of each attribute. The results of the analysis include four different suggestions based on measures of importance and the quality or condition of the space (performance), which can then be used as a basis for setting further recommendations. This analysis begins with a questionnaire distributed to the Graha Jangli Indah community, each question has two answers on a scale of 1 to 5 , namely whether according to the community it is important to do or be carried out and how it performs, good or bad. With the Cartesian diagram which is a rectangular section that is bounded by two lines that intersect perpendicular to the points $(\mathrm{X}, \mathrm{Y})$, where $\mathrm{X}$ is the average of the average performance scores of all indicators and $\mathrm{Y}$ is the average of the average score of importance for all indicators that influence expectations as explained as follows:

1. Quadrant IV (First Priority Quadrant) shows factors that are considered very important, but the form of clean water supply has not met the needs according to the wishes or expectations of the people of Graha Jangli Indah.

2. Quadrant III (Low Priority Quadrant) indicates factors that are considered less important, and the provision of clean water meets the needs of the Graha Jangli Indah
$4 \quad$ Fakultas Teknik UMSB
ISSN 2599-2081

EISSN 2599-2090 
community in a sufficient or ordinary manner.

3. Quadrant II (Excessive Quadrant) shows a less important factor but the form of clean water supply meets the needs of the community in Graha Jangli Indah in excess or very satisfactory.

4. Quadrant I (Quadrant of Achievement) shows the factors that are considered important, and the form of clean water supply has succeeded in meeting the needs of the community and Graha Jangli Indah according to their wishes or expectations and is very satisfying so it must be maintained.

\section{RESEARCH METHODOLOGY \\ Performance Analysis Based on Water Discharge}

This study also requires data obtained from the results of recording and storing data from Graha Jangli Indah in Semarang City in the form of a measured monthly discharge on each household water meter for at least 1 year $(\mathrm{m} 3$ / mo). For this study, we used data for 13 months (August 2018 - September 2019) that we got from the Graha Jangli Indah Water Management. Previously calculated Minimum House Debit $=$ number of occupants per house x 170 x 30 days / 1000. Then you will get a Minimum House Debit $\left(\mathrm{m}^{3}\right)$, this minimum debit will be different for each house because the number of each house has a different number of occupants.

For research methodology schemes for performance analysis based on water discharge can be seen in Figure.1.

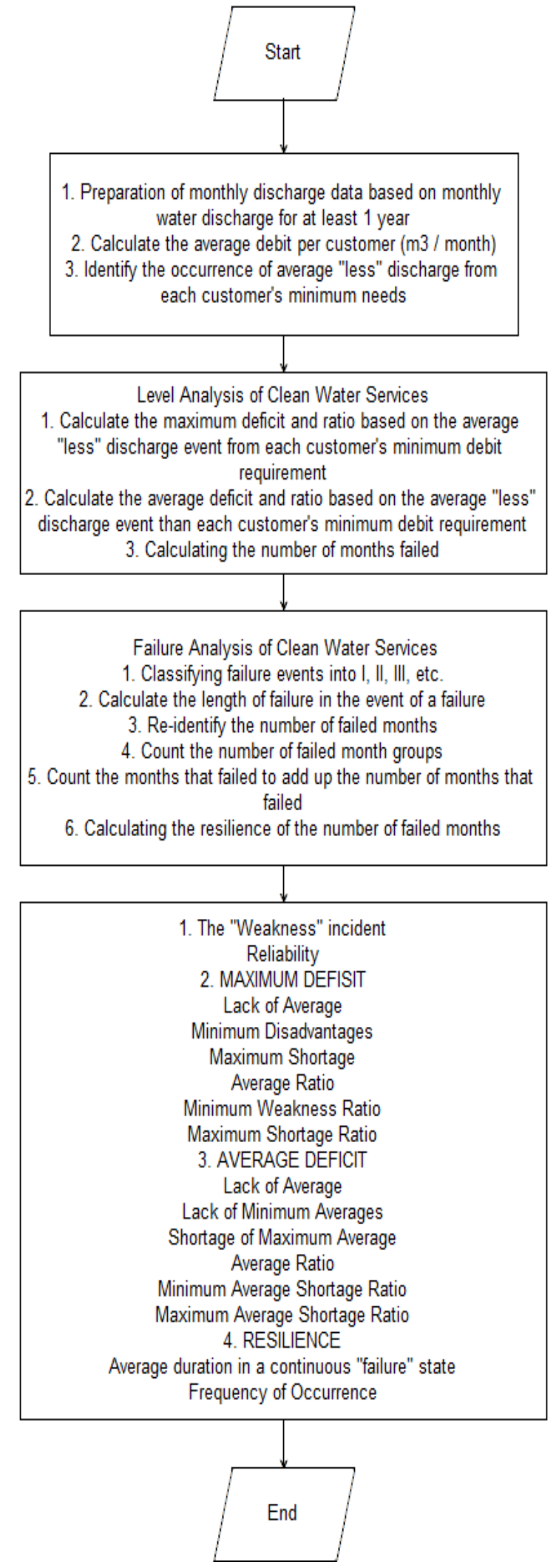

Figure.1 


\section{Performance Analysis Based on IPA and CSI}

Performance appraisal based on IPA and CSI uses questionnaire data distributed to residents of Graha Jangli Indah. To determine the overall customer satisfaction performance assessment of the quality of clean water services conducted by the Graha Jangli Indah Water Management, the Customer Statisfaction Index (CSI) is calculated. CSI is calculated from the average value for the level of importance and level of performance of each of the quality attributes of clean water services. There were 18 questionnaire questions for the provision of clean water that were rated for the level of performance and importance of the respondents, including:

1 . Is the water drinkable?

2. Does the water smell?

3 . Is the water cloudy?

4. Is mossy water?

5 . Does water contain iron?

6. Does water contain lime?

7. Does water available 24 hours?

8 . Is the water pressure strong?

9. Is water sufficient for daily needs?

10. Satisfied new customer registration procedure?

11. Satisfying monthly payment procedure?

12. Careful officers record monthly usage?

13. Friendly and polite staff?

14. The officer is fast and responsive to customer complaints?

15. Is the Water Board open to suggestions and criticisms?

16. Are the water tariffs affordable enough?

17. Officers submit information if there is damage?

18. The officer is easy to contact?

Customer Satisfaction Index (CSI) is used to determine the level of customer satisfaction with the results of service performance by looking at the level of importance of the service attributes. Analysis of Customer Satisfaction Index (CSI) data is a quantitative analysis of the percentage of happy customers in a customer satisfaction survey. CSI is needed to determine the level of overall customer satisfaction by taking into account the importance of the attributes of the product or service. The calculation method to get the CSI value is the way the average value in the interest column (I) is summed to obtain $\mathrm{Y}$ and also the product times I with $\mathrm{P}$ in the score column (S) are summed and obtained T. CSI is obtained from the calculation (T / 5Y) x $100 \%$ Value 5 (at $5 \mathrm{Y}$ ) is the maximum value used on the measurement scale.

In Table 1 can be seen indicators of the value of CSI on consumer satisfaction.

Table 1

Customer Satisfaction Index Value Criteria

\begin{tabular}{|c|c|}
\hline CSI value & Criteria CSI \\
\hline$<60 \%$ & Bad \\
\hline $60 \%-75 \%$ & Enough \\
\hline $76 \%-85 \%$ & Good \\
\hline $85 \%-95 \%$ & Very Good \\
\hline$>95 \%$ & Satisfying \\
\hline
\end{tabular}

In this study, there are 2 variables that are represented by the letters $\mathrm{X}$ and $\mathrm{Y}$, where $\mathrm{X}$ is the level of water supply performance that can provide performance for the community, while $\mathrm{Y}$ is the level of expectation or interest for the community regarding the provision of clean water they get. A Cartesian diagram is made by dividing a chart into four parts that are bounded by two lines that intersect perpendicular to the points $\mathrm{X}$, and $\mathrm{Y}$, where $\mathrm{X}$ is the average of the average value of the performance level for all indicators, while $\mathrm{Y}$ is the average - the average value of the importance of all indicators that affect the performance of the community towards the provision of clean water in Graha Jangli Indah

A Cartesian diagram is made by dividing a chart into four parts bounded by two lines that intersect perpendicular to the points $\mathrm{X}$, and $\mathrm{Y}$, where $\mathrm{X}$ is the average of the average value of the performance level for all indicators, while $\mathrm{Y}$ is the average of the average value of the importance of all indicators that affect the performance of the community towards the provision of clean water in Graha Jangli Indah. From the determination of the $\mathrm{X}$ and $\mathrm{Y}$ coordinates can be made a diagram of Importance and Performance Analysis (IPA).

\section{RESULTS AND DISCUSSION \\ Performance Analysis Based on Water Discharge}

From the analysis of the minimum water discharge table, monthly water discharge, failure, failure event and resilience at Graha Jangli Indah, an analysis of clean water 
performance based on water discharge is obtained as in Table 2.

Table 2. Performance Based on Water

Discharge in Graha Jangli Indah

\begin{tabular}{|c|c|c|c|}
\hline NO & PARAMETER & \multicolumn{2}{|c|}{ UNIT VALUE } \\
\hline \multirow[t]{2}{*}{1} & "Weakness" incident & 50,67 & $\%$ \\
\hline & Reliability & 49,33 & $\%$ \\
\hline \multirow[t]{7}{*}{2} & $\begin{array}{l}\text { MAXIMUM } \\
\text { DEFICIT }\end{array}$ & & \\
\hline & Average Shortage & 9,8 & $\mathrm{~m}^{3}$ \\
\hline & Minimum Shortage & 0,2 & $\mathrm{~m}^{3}$ \\
\hline & Maximum Shortage & 20,6 & $\mathrm{~m}^{3}$ \\
\hline & Average Ratio & 54,92 & $\%$ \\
\hline & $\begin{array}{l}\text { Minimum Shortage } \\
\text { Ratio }\end{array}$ & 1,12 & $\%$ \\
\hline & $\begin{array}{l}\text { Maximum Shortage } \\
\text { Ratio }\end{array}$ & 115,63 & $\%$ \\
\hline \multirow[t]{7}{*}{3} & DEFICIT AVERAGE & & \\
\hline & Average Shortage & 6,49 & $\mathrm{~m}^{3}$ \\
\hline & $\begin{array}{l}\text { Minimum Average } \\
\text { Shortage }\end{array}$ & 0,12 & $\mathrm{~m}^{3}$ \\
\hline & $\begin{array}{l}\text { Maximum } \\
\text { Shortage }\end{array}$ & 18,2 & $\mathrm{~m}^{3}$ \\
\hline & Average Ratio & 36,41 & $\%$ \\
\hline & $\begin{array}{l}\text { Minimum Average } \\
\text { Shortage Ratio }\end{array}$ & 1,12 & $\%$ \\
\hline & $\begin{array}{l}\text { Maximum Average } \\
\text { Shortage Ratio }\end{array}$ & 102,11 & $\%$ \\
\hline \multirow[t]{3}{*}{4} & RESILIENCE & & \\
\hline & $\begin{array}{l}\text { Average Duration in a } \\
\text { "Failed" State } \\
\text { Continuously }\end{array}$ & 5,83 & month \\
\hline & $\begin{array}{l}\text { Frequency } \\
\text { Occurrence }\end{array}$ & 1,03 & time \\
\hline
\end{tabular}

\section{Performance Analysis Based on Customer Satisfaction Index (CSI)}

From the questionnaire data processing, it is obtained the average weighting value of importance and performance can be seen in Table 3

Table 3. CSI Calculation

\begin{tabular}{|c|c|c|c|}
\hline NO & $\mathbf{K}$ & $\mathbf{I}(\mathbf{Y})$ & $\mathbf{T}$ \\
\hline 1 & 3,6 & 2,7 & 9,84 \\
\hline 2 & 4,1 & 3,8 & 15,55 \\
\hline 3 & 4,2 & 3,7 & 15,73 \\
\hline 4 & 3,9 & 3,9 & 15,11 \\
\hline 5 & 3,9 & 3,3 & 12,67 \\
\hline
\end{tabular}

\begin{tabular}{|c|c|c|c|}
6 & 4,3 & 3,5 & 14,80 \\
\hline 7 & 4,6 & 4,2 & 19,09 \\
\hline 8 & 4,4 & 4,2 & 18,25 \\
\hline 9 & 4,7 & 4,3 & 20,51 \\
\hline 10 & 4,3 & 4,1 & 17,68 \\
\hline 11 & 4,4 & 4,1 & 18,29 \\
\hline 12 & 4,5 & 3,9 & 17,51 \\
\hline 13 & 4,6 & 4,2 & 19,33 \\
\hline 14 & 4,4 & 3,8 & 16,89 \\
\hline 15 & 4,4 & 3,9 & 17,19 \\
\hline 16 & 4,5 & 3,1 & 13,84 \\
\hline 17 & 4,2 & 2,9 & 12,21 \\
\hline 18 & 4,4 & 3,1 & 13,55 \\
\hline & TOTAL & $\mathbf{6 6 , 8}$ & $\mathbf{2 8 8 , 0 5}$ \\
\cline { 2 - 4 }
\end{tabular}

CSI Value $=(288,05) /(5 \times 66,8)=86,28 \%$

The maximum value of CSI is $100 \%$. A CSI value of $50 \%$ or lower indicates poor service performance. CSI value of $76 \%$ or higher indicates that the customer is satisfied with the service performance. From the CSI value calculation results are above $85 \%$, this means that customers in this case residents of Graha Jangli Indah have rated the performance of the services of the Graha Jangli Indah Managers with very good grade.

Performance Analysis Based on Analysis of Customer Satisfaction Index (IPA)

To get the Importance and Performance Analysis (IPA) diagram the results of the importance and performance results are averaged to obtain the $\mathrm{x}$ and $\mathrm{Y}$ ordinate. The results of calculating the average value of the indicators can be seen in Table 4 .

Table 4. Average Indicator Value

\begin{tabular}{|c|c|c|}
\hline NO & Performance & Importance \\
\hline 1 & 3,6 & 2,7 \\
\hline 2 & 4,1 & 3,8 \\
\hline 3 & 4,2 & 3,7 \\
\hline 4 & 3,9 & 3,9 \\
\hline 5 & 3,9 & 3,3 \\
\hline 6 & 4,3 & 3,5 \\
\hline 7 & 4,6 & 4,2 \\
\hline 8 & 4,4 & 4,2 \\
\hline 9 & 4,7 & 4,3 \\
\hline 10 & 4,3 & 4,1 \\
\hline
\end{tabular}




\begin{tabular}{|l|l|l|}
11 & 4,4 & 4,1 \\
\hline 12 & 4,5 & 3,9 \\
\hline 13 & 4,6 & 4,2 \\
\hline 14 & 4,4 & 3,8 \\
\hline 15 & 4,4 & 3,9 \\
\hline 16 & 4,5 & 3,1 \\
\hline 17 & 4,2 & 2,9 \\
\hline 18 & 4,4 & 3,1 \\
\hline & $\mathbf{7 7}$ & $\mathbf{6 7}$ \\
\cline { 2 - 3 }
\end{tabular}

$$
\mathrm{X}=77 / 18=4,29 \quad \mathrm{Y}=67 / 18=
$$

By using the Average Performance Level Score (X) and Expectation (Y), it is found that the Cartesian diagram of the Graha Jangli Indah has an $\mathrm{X}$ coordinate value at 4.29 and $\mathrm{Y}$ coordinate value at 3.7. From the determination of $\mathrm{X}$ and $\mathrm{Y}$ coordinates can be made diagram of Importance and Performance Analysis IPA with 4 quadrants according to Figure 2. From the picture can be seen the results of the Importance and Performance Analysis (IPA) diagram.

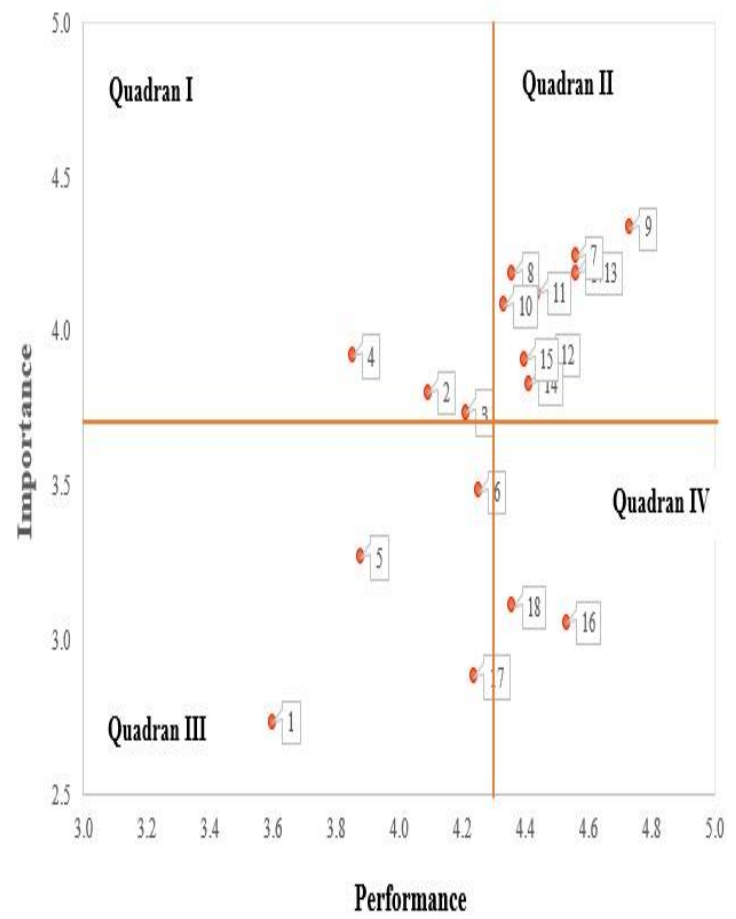

Figure 2. IPA Diagram Mapping

1. Quadrant IV (First Priority Quadrant) that the indicator has a high performance value but has a low importance value. Indicators included in this quadrant are the staff's response to complaints, affordable water costs and whether the staff is easy to contact.

2. Quadrant III (Low Priority Quadrant) means that the performance value is low and the value of interests is also low. Indicators that enter this quadrant are potable water, turbid water, iron-containing water, limecontaining water and the officer submits information if there is damage.

3. Quadrant II (Quadrant of Achievement) which means the indicator has a high performance value and high importance value. Indicators that enter this quadrant are 24-hour running water, strong water pressure, sufficient water for daily needs, new registration procedures, satisfactory payment procedures, careful recording of officers, friendly courteous officers and administrators open to suggestions and criticisms.

4. Quadrant I (First Priority Quadrant) which means that the indicator has a low performance value but has a high importance value includes. Indicators that enter this quadrant are smelly water, turbid water and mossy water.

\section{CONCLUSIONS}

\section{Performance Analysis Based on Water Discharge}

From the analysis of water performance based on parameters of reliability, resilience, and vulnerability. In Table 2 it can be seen that at the study site the largest average failure time of 13 months was found in 20 customers, which means that in each 1 event of succession there were 13 months of failure, while the least failure event was 1 time fail happened to 4 customers. Likewise, when viewed in the event of a "failure" of the system as a whole, the average length of the system experiencing water shortages (failing) continuously is around 5.83 months. The frequency of occurrence of resilience on average is 1.03 times. Overall, the service level of the clean water network at Graha Jangli Indah is still unsatisfactory, with a reliability of only around $49.33 \%$, with the duration of the system being in a failed state of around 5.83 months, and with an average percentage deficit level debit varies greatly between $1.12 \%$ to $102.11 \%$. So that the system's resilience index or ability to return to 
normal conditions is 0.049 ( 0.29 times failure divided by 5.83 months). This is because the average discharge at Graha Jangli Indah has an average water discharge value of $17.8 \mathrm{~m} 3$ per month which is still below the standard water requirement based on Domestic Water Needs for the Big City category of $20.4 \mathrm{~m} 3$ per month. So it can be concluded that the performance of clean water network based on water discharge is still not satisfactory.

\section{Performance Analysis Based on Analysis of Customer Satisfaction Index (IPA) and Customer Satisfaction Index (CSI)}

For performance assessment based on customer satisfaction, the assessment uses the Customer Statisfaction Index (CSI) and Importance and Performance Analysis (IPA) analysis methods. Where from the 75 questionnaire data, the conclusion for the Customer Statisfaction Index (CSI) analysis method was $86.28 \%$, or in other words according to the customer that the Graha Jangli Indah Water Management has a very good value. For the Importance and Performance Analysis (IPA) analysis method, the majority of indicators are in Quadrant II (7 indicators), Quadrant III (4 indicators), Quadrant IV (2 indicators) and Quadrant I (3 indicators). Quadrant II (Quadrant of Achievement) which means that the indicator has a high performance value and a high importance value for the residents of Graha Jangli Indah. Indicators that enter this quadrant are 24-hour running water, strong water pressure, sufficient water for daily needs, new registration procedures, satisfactory payment procedures, careful recording of officers, friendly courteous officers and administrators open to suggestions and criticisms. With 7 indicators entering quadrant II so that conclusions can be drawn by the Importance and Performance Analysis (IPA) method, the performance of the Graha Jangli Indah Water Management is quite satisfying.

\section{REFERENCES}

[1] Agustina, D.V., 2007, 'Analisa Kinerja Sistem Distribusi Air Bersih PDAM Kecamatan Banyumanik di Perumnas Banyumanik (Studi Kasus) Perumnas Banyumanik Kel. Srondol Wetan)', Tesisi, Program Pasca Sarjana Magister
Teknik Sipil Universitas Diponegoro Semarang.

[2] Badan penelitian dan Pengembangan Departemen PU 2006, Pedoman /Petunjuk Teknik dan Manual,Bagian: 6 Volume VI Petunjuk Teknik Air Minum Perkotaan, Departemen PU, Jakarta.

[3] Badan Litbang Departemen Pekerjaan Umum. (2005). Penyediaan Air Minum Berbasis Masyarakat (PAM BM) Jakarta: Litbang Departemen Pekerjaan Umum

[4] Damanhuri, E., 1989, 'Pendekatan Sistem Dalam Pengendalian dan Pengoperasian Sistem Jaringan Distribusi Air Minum', Jurusan Teknik Lingkungan ITB, Bandung.

[5] Fitriadi, 2013, 'Rancangan Strategi Peningkatan Kapasitas Produksi Pada Sistem Distribusi Produksi Air PDAM Tirta Meulaboh, Kabupaten Aceh Barat', Magister Teknik Industri Universitas Sumatera Utara, Medan.

[6] Ibrahim, M., ' Analisa Hidrolis Pada Komponen Sistem Distribusi Air Bersih Dengan Waternet dan Watercad Versi 8 (Studi Kasus Kampung Digiouwa, Kampung Mawa dan Kampung Ikebo, Distrik Kamu Kabupaten Dogiyai)', Magister Teknik Pengairan Universitas Brawijaya, Malang.

[7] Idris, F., 2012, 'Analisa Kinerja Jaringan Distribusi Air Bersih Di Perumnas Lingke Kecamatan Syiah Kuala Kota Banda Aceh', Magister Teknik Sipil Universitas Syiah Kuala, Banda Aceh.

[8] Maisimin dan Ariff, Z.A., 2012 , An Overview of Water Supply Provision for the City of Banda Aceh', Proceedings of Water Supply Management System And Social Capital, Volume 3, PP. 205-213.

[9] Menteri Pekerjaan Umum. (2007). Peraturan Menteri Pekerjaan Umum No: 18/PRT/M/2007 Tentang: Penyelenggaraan pengembangan sistem penyediaan air minum. Jakarta: Kementerian Pekerjaan Umum.

[10] Muhadjir, N. (1996). Metodologi penelitian Kualitatif. Yogyakarta: PT. Bayu Indra Grafika

[11] Nugraha, W.D, 2010, 'Studi Kehilangan Air Akibat Kebocoran Pipa Pada Jalur Distriusi PDAM Kota Magelang (Studi Kasus: Perumahan Armada Estate). 
[12] Dan Depkes, Kramat Utara, Kecamatan Magelang Utara', Volume 7, No. 2, September 2010, ISSN 1907-187X.

[13] Keputusan Menteri Kesehatan Republik Indonesia Nomor : 416/Menkes/PER/IX/1990 Syarat -Syarat dan Pengawasan Kualitas Air Bersih

[14] Putrabahar, A., 2010, 'Teori dan Konsep Sistem Penyaluran Air Minum', Jurusan Teknik Lingkungan, Fakultas Teknik Sipil dan Perencanaan Institut Teknologi Sepuluh Nopember,Surabaya.

[15] Peraturan Pemerintah RI Nomor 16 Tahun 2005 Tentang Pengembangan Sistem Penyediaan Air Minum, (2005).

[16] Restu, A., 2003, 'Analisa Pelayanan Air Bersih PDAM di Kampung Pejaten Kelurahan Rejomulyo Semarang', Jurnal Tesis, Program Magister Teknik Sipil Universitas Diponegoro, Semarang.

[17] Rosadi, M.I., 2011, 'Perencanaan Pengembangan Sistem Jaringan Distribusi PDAM IKK Durenan Kabupaten Trenggalek', Jurnal Tesis, Teknik Sipil Institut teknologi Sepuluh Nopember, Surabaya.

[18] Siregar, N.A., 2014, 'Evaluasi Kehilangan Air (Water Losses) PDAM Tirtanadi Padangsidimpuan Di Kecamatan Padangsidimpuan Selatan', Fakultas Teknik Sipil Universitas Sumatera Utara, Medan.

[19] Suhardi, 2007, 'Kajian Spasial Tingkat Pelayanan Air Bersih di Perumahan Limbangan Baru Kabupaten Banjar Negara', Tesis, Program Pasca Sarjana Universitas Diponegoro, Semarang.

[20] Suharyanto \& Pranoto S.A. 1999. Analisa Pelayanan Jaringan Air Bersih. Media Komunikasi Teknik Sipil, BMPTTSSI,Edisi Desember 1999.

[21] Suharyanto, Sugiyanto, Nasrullah, Sri Sangkawati. 1999. Peningkatan Efisiensi dan Tingkat Layanan Pengoperasian Jaringan Air Bersih. Laporan Penelitian, EEDP Batch III 1998/1999.

[22] Sugiyono. (2012). Metode Penelitian Kuantitatif Kualitatif dan R\&D. Bandung: Alfabeta.

[23] Syahputra, B., 2005, ' Pengaruh Penambahan Debit Kebutuhan Pada Zona Layanan Air Bersih Di PDAM Tirta Meulaboh', Fakultas Teknik Jurusan
Teknik Lingkungan Universitas Islam Sultan Agung, Semarang.

[24] Triadmaja R., 2008, 'Studi Beberapa Kriteria Hydraulic Critical Index (Link Importance) Pada Jaringan Pipa', Magister Pengelolaan Sumberdaya Air Jurusan Teknik Sipil dan Lingkungan Universitas Gajah Mada, Yogyakarta.

[25] Triatmodjo, B 2003, 'Hidraulika I dan II', Edisi Ketiga, Beta Offset, Jakarta.

[26] Triatmadja, Radianta, 2009, Hidraulika Sistem Jaringan Perpipaan Air Minum, Yogyakarta, Beta Offset. 